\title{
Analisa Pengaruh Lama Waktu Tahan Tempering terhadap Struktur Mikro dan Sifat Mekanik Coulper Baja AAR-M201 Grade E
}

\author{
Rinelda Nena Sagita, Rochman Rochiem, dan Alvian Toto Wibisono \\ Jurusan Teknik Material dan Metalurgi, Fakultas Teknologi Industri, Institut Teknologi Sepuluh \\ Nopember (ITS) \\ Jl. Arief Rahman Hakim, Surabaya 60111 Indonesia \\ e-mail: rochman@mat-eng.its.ac.id
}

\begin{abstract}
Abstrak-Coupler adalah penyambung pada gerbong kereta api satu dengan gerbong yang lainnya. Material coupler adalah baja AAR-M201 Grade E yang spesifikasinya sesuai dengan standar AARManual of Standards and Recomended Practices Couplers and Freight Car Draft Components. Penelitian ini membahas perlakuan panas disertaitempering dan hardening. Tujuan dari penelitian ini adalah menganalisa pengaruh lama waktu tahan terhadap struktur mikro dan sifat mekanik pada baja AAR-M201 Grade E. Proses perlakuan panas yang dilakukan adalah hardening pada temperatur $925^{\circ} \mathrm{C}$ dengan waktu tahan $3 \mathrm{jam}$, kemudian di tempering pada temperatur $600^{\circ} \mathrm{C}$ dengan variasi waktu tahan 2 jam, 3 jam dan 4 jam. Pengujian yang dilakukan pada penilitian ini adalah uji tarik untuk mengetahui kekuatan maksimum, keuletan dan ketangguhan baja. Hasil pengujian metalografi pada tempering menghasilkan struktur mikro asikular ferrit, dan hasil sifat mekanik paling optimal didapat dari proses hardening-tempering pada lama waktu tahan 3 jam, menghasilkan nilai kekuatan tarik 870 MPa, kekuatan luluh 782 MPa, elongasi $14 \%$, reduksi area 38\%, kekerasan $264 \mathrm{BHN}$, kekuatan impak sebesar 35 Joule pada temperatur $-40^{\circ} \mathrm{C}$ dan nilai fatigue life 5100 cycle. Nilai yang dihasilkan seluruhnya memenuhi standar AAR, kecuali nilai elongasi yang hampir memenuhi standar AAR.
\end{abstract}

Kata Kunci-Baja AAR-M201 Grade, Hardening, Lama waktu tahan, Tempering.

\section{PENDAHULUAN}

$\mathrm{K}$ EMAJUAN industri di era sekarang sangatlah pesat. Baja merupakan material yang sangat banyak penggunaannya dalam dunia otomotif maupun dunia industri lainnya. Salah satu produk PT Barata Indonesia adalah baja AAR M201 grade Eberupa coupler yang digunakan sebagai penyambung antar gerbong pada kereta api. Spesifikasi baja AAR-M201 Grade E ini ditentukan oleh AARManual of Standards and Recomended Practices Couplers and Freight Car Draft Components. Namun, proses yang selama ini dilakukan hanya beberapa yang dapat memenuhi standar spesifikasi baja tersebut. Maka dari itupengembangan proses perlakuan panas dilakukan terhadap baja AAR M201 grade E untuk mencari perlakuan yang sesuai dan memenuhi spesifikasi tersebut. Proses perlakuan panas untuk baja AAR-M201 Grade E pada penelitian ini yang digunakan adalah hardening dan tempering.

Perlakuan panas dapat didefinisikan sebagai kombinasi perlakuan pemanasan dan pendinginan terhadap logam dengan waktu tertentu, dimaksudkan untuk memperoleh sifat tertentu juga. Pemberian proses perlakuan panas terhadap baja memiliki tujuan yang bermacam-macam seperti untuk homogenisasi struktur mikronya, untuk memperhalus ukuran butirnya, menaikkan kekerasan, menambah keuletan, meningkatkan machinability ataupun untuk tujuan lainnya. Maka untuk mendapatkan sifat-sifat tersebut diperlukan proses perlakuan panas yang berbeda. Perbedaan tersebut juga mencakup perbedaan pada tingginya temperatur pemanasan, lamanya waktu tahan pada temperatur pemanasan, laju pendinginan dan media pendinginannya. Semua hal tersebut harus memperhatikan komposisi unsur paduan dari suatu materialnya.

Dalam penelitian ini, proses perlakuan panas yang dilakukan adalah perlakuan panas hardening pada temperatur $925^{\circ} \mathrm{C}$ kemudian dilanjutkan dengan proses perlakuan panas tempering pada temperatur $600^{\circ} \mathrm{C}$ dengan variasi lama waktu tahan selama 2, 3, dan 4 jam. Kemudian akan diamati bagaimana pengaruh lama waktu tahan tempering yang telah divariasikan terhadap struktur mikro dansifat mekanik yang nanti akan terbentuk.

Rumusan masalah pada penelitian ini adalah untuk mengetahui perngaruh lama waktu tahan tempering terhadap struktur mikro dan sifat mekanik baja AAR-M201 Grade E.

\section{Metodologi PENELITIAN}

\section{A. Material}

Material yang digunakan pada penelitian ini adalah Baja AAR-M201 Grade E yang di dapat dari PT. Barata Indonesia dengan komposisi kimia seperti pada Tabel 1.

$$
\text { Tabel } 1
$$

Komposisi kimia baja AAR-M201 Grade E

\begin{tabular}{lc}
\hline \hline \multicolumn{1}{c}{ Unsur } & Berat $(\%)$ \\
\hline $\mathrm{C}$, maks 0.32 & $\mathbf{0 . 2 8 2}$ \\
$\mathrm{Si}$, maks 1.50 & $\mathbf{0 . 4 2 5}$ \\
$\mathrm{Mn}$, maks 1.85 & $\mathbf{1 . 4 6 9}$ \\
$\mathrm{P}$, maks 0.04 & $\mathbf{0 . 0 2}$ \\
$\mathrm{S}$, maks 0.04 & $\mathbf{0 . 0 0 1}$ \\
$\mathrm{Cr}$ & $\mathbf{0 . 4 7}$ \\
$\mathrm{Mo}$ & $\mathbf{0 . 3 0 8}$ \\
$\mathrm{Cu}$ & $\mathbf{0 . 0 2 1}$ \\
$\mathrm{Ni}$ & $\mathbf{0 . 3 6 8}$ \\
$\mathrm{Al}$ & $\mathbf{0 . 0 7 7}$ \\
$\mathrm{Fe}$ & Balance \\
\hline
\end{tabular}

B. Preparasi Spesimen

Preparasi spesimen dimulai dari pemotongan spesimen 
berbentuk $Y$-block menjadi spesimen uji tarik, uji impak dan uji fatik.

\section{Heat Treatment}

Perlakuan panas baja AAR-M201 Grade E dilakukan dengan hardening pada temperatur $925^{\circ} \mathrm{C}$ yang ditahan selama 3 jam dan pendinginan dengan media air. Perlakuan panas dilanjutkan dengan tempering pada temperatur $600^{\circ} \mathrm{C}$, variasi waktu tahan tempering adalah 2 jam, 3 jam dan 4 jam.

\section{Uji Metalografi}

Pengujian pada penelitian ini adalah pengujian metalografi ini bertujuan untuk mengetahui fasa, bentuk dan ukuran struktur mikro pada baja AAR M201 Grade E. Selain itu juga untuk memprediksikan mikrostruktur yang terbentuk setelah proses perlakuan panas, pengujian ini menggunakan standar ASTM E3. Komposisi etsa yang digunaka seperti pada table 2 .

Tabel 2

Komposisi Etsa

\begin{tabular}{cl}
\hline \hline Nama Etsa & \multicolumn{1}{c}{ Komposisi } \\
\hline Nital & $1-5 \mathrm{~mL}$ nitric acid $\left(\mathrm{HNO}_{3}\right)$ \\
& $100 \mathrm{~mL}$ athanol $95 \%$ \\
Pikral & 4 gram picric acid $\left(\left(\mathrm{NO}_{2}\right)_{3} \mathrm{C}_{6} \mathrm{H}_{2} \mathrm{OH}\right)$ \\
& $100 \mathrm{~mL}$ ethanol $95 \%$ \\
\hline \hline
\end{tabular}

\section{E. Uji Tarik}

Uji tarik banyak dilakukan untuk melengkapi informasi rancangan dari kekuatan satu bahan dan sebagai data pendukung bagi spesifikasi bahan. Uji tarik bertujuan untuk mengetahui nilai kekuatan dan keuletan benda kerja. Pengujian ini sesuai dengan standar ASTM E8.

\section{F. Uji Kekerasan}

Pengujian kekerasan bertujuan untuk mengetahui kekerasan baja AAR-M201 Grade E tanpa perlakuan dan dengan perlakuan panas. Standar yang digunakan pada pengujian ini dengan menggunakan ASTM A370 Standard Test Methodes and Definition for Mechanical Testing of Steel Productsdengan metode Brinnel.

\section{G. Uji Impak}

Pengujian impak dilakukan untuk mengetahui ketangguhan dari baja AAR-M201 Grade E, yang ditunjukkan dari hasil kekuatan impaknya. Pengujian dilakukan sesuai standar ASTM E23 Standard Test Methods for Notched Bar Impact Testing of Metallic Materials. Pengujian menggunakan metode Charpy, pada tiga temperatur yang berbeda yaitu $0,-40,-60{ }^{\circ} \mathrm{C}$.

\section{H. Uji Fatik}

Pengujian fatik bertujan untuk mengetahui masa kerja dari material dan kecenderungan material untuk patah atau rusak jika menerima beban yang berulang dengan beban jauh dibawah batas kekuatan elasitis material tersebut. Pengujian ini menggunakan standar ASTM E 606 - 92.

\section{HASIL DAN PEMBAHASAN}

\section{A. Uji Struktur Mikro}

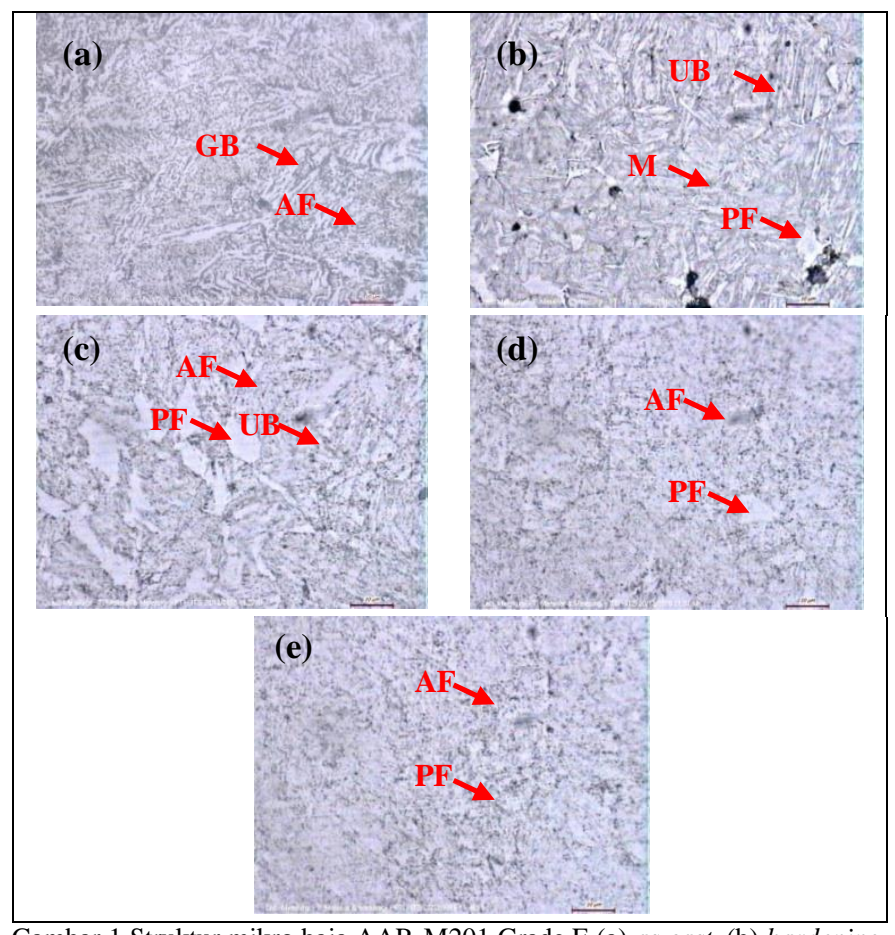

Gambar 1 Struktur mikro baja AAR-M201 Grade E (a) as cast, (b) hardening, (c) tempering $600^{\circ} \mathrm{C}$ waktu tahan 2 jam, (d) tempering $600^{\circ} \mathrm{C}$ waktu tahan 3 jam dan (e) tempering $600^{\circ} \mathrm{C}$ waktu tahan 4 jam. AF: asikular ferrit; GB: grain boundary ferrite; UB: upper bainit; M: martensit; PF: poligonal ferrit.

Gambat 1 merupakan struktur mikrograf hasil perlakuan panas baja AAR M201 Grade E. Gambar 1 (a) menunjukkan struktur mikroas cast. Material as cast menghasilkan struktur mikro acicular ferrite dan grain boundary ferrit. Struktur ini terbentuk akibat benda kerjayang telah mengalami pendinginan yang tidak normal selama proses manufaktur. Gambar 1(b) menunjukkan struktur mikro AAR M201 Grade E yang telah mengalami perlakuan hardening dengan pemanasan pada tempertaur $925^{\circ} \mathrm{C}$ selama 3 jam kemudian di quench menggunakan air. Setelah perlakuan hardening, strukturmikro yang terbentuk adalah poligonal ferrit, upper bainit dan martensit. Struktur ini terbentuk akibat benda kerja mengalami pendinginan cepat menggunakanmedia air. Gambar 1 (c) menunjukkan struktur mikro AAR M201 Grade E yang telah mengalami perlakuan hardening dengan pemanasan pada tempertaur $925^{\circ} \mathrm{C}$ selama 3 jam kemudian di quench menggunakan air dan dilanjutkan dengan tempering. Tempering dilakukandengan memanaskan AAR M201 Grade E pada temperatur $600^{\circ} \mathrm{C}$ dengan lama waktu tahan 2 jam. Setelah benda kerja mengalami perlakuan tempering, struktur mikro yang terbentuk adalah upper bainit, asikular ferrit dan poligonal ferrit. Pada diagram CCT HSLA, pada temperatur tempering $600^{\circ} \mathrm{C}$ dengan waktu tahan 2 jam akan menyentuh 3 daerah yang berbeda, yakni, upper bainit, asikular ferrit dan poligonal ferrit. Pada Gambar 1 (d) merupakan hasil struktur mikro AAR M201 Grade E, struktur tersebut dihasilkan dariperlakuan tempering pada temperatur $600^{\circ} \mathrm{C}$ dengan lama waktu tahan 3 jam. Struktur mikro hasil perlakuan tersebut adalah asikular ferrit dan poligonal ferrit. Pada Gambar 1 (e) merupakan hasil struktur mikro AAR M201 Grade E, struktur tersebut dihasilkan 
dari perlakuan tempering pada temperatur $600^{\circ} \mathrm{C}$ dengan lama waktu tahan 4 jam. Struktur mikro hasil perlakuan tersebut adalah asikular ferrit dan poligonal ferrit dengan jumlah yang relatif sedikit. Proses perlakuan panas hardening-tempering akan menghasilkan struktur mikro yang berbeda.

Pada kondisi as cast struktur mikro yang terbentuk adalah asikular ferrit dan grain boundary ferrit. Asikular ferrit memiliki bentuk struktur seperti jarum. Fasa yang terdapat pada asikular ferrit adalah ferrit dan sementit yang berbentuk seperti jarum yang tersebar merata. Sedangkan grain boundary ferrit seperti sungai yang mengelilingi asikular ferrit. Fasa pada grain boundary ferrit adalah ferrit dan jaringan sementit. Struktur tersebut terbentuk akibat pendinginan yang tidak normal selama proses manufaktur, austenit bertransformasi membentuk ferrit yang belum sempurna dengan bentuk butir seperti bulu.

Perlakuan hardening dengan memanaskan pada termperatur $925^{\circ} \mathrm{C}$ selama 3 jam dan di quench menghasilkan struktur mikro upper bainit, martensit dan poligonal ferrit. Bentuk struktur upper bainit adalah bulu dengan platelet. Transfomasi bainit terjadi akibat laju pendinginan yang cepat. Pendinginan yang cepat mengakibatkan austenit tidak mempunyai waktu yang cukup untuk bertransformasi menjadi perlit, sehingga struktur yang terbentuk hampir menyerupai perlit, yaitu bainit. Pada proses transformasinya, austenit mengalami driving force yang besar untuk berubah dari FCC (Face Centered Cubic) menjadi BCC (Body Centered Cubic), sehingga terbentuk ferrit. Ferrit mempunyai nilai kelarutan karbon yang kecil, sehingga karbon yang tidak mampu dilarutkan ferit berdifusi keluar membentuk karbida sementit $\left(\mathrm{Fe}_{3} \mathrm{C}\right)$. Austenit yang bertransformasi menjadi ferit dan karbon yang berdifusi keluar membentuk karbida, menghasilkan struktur berupa bilah-bilah ferit yang saling terhubung dan didalamnya terdapat partikel sementit yang memanjang dengan arah hampir sejajar dengan sumbu pertumbuhannya. Jumlah dan kontinuitas layer sementit dipengaruhi oleh kadar karbon baja. Struktur mikro bainit yang terbentuk pada baja ini adalah bainit atas (Bhadhesia, 2001). Struktur tersebut terdiri dari fasa ferrit yang berbentuk bilah dan platelet karbida sementit yang tersebar didalamnya. Struktur martensit berbentuk seperti jarum. Struktur martensit terbentuk akibat pendinginan sangat cepat, atom karbon yang seharusnya keluar dari larutan akan terperangkap dalam struktur baru (atom karbon tidak lagi dapat berdifusi keluar karena ia sudah tidak lagi memiliki cukup energi untuk berdifusi) dan menyebabkan struktur baru itu terdistorsi, tidak menjadi BCC tetapi menjadi BCT (body centered tetrafonal), yaitu martensit yang tampak seperti jarum (Avner, 1974). Fasa pada martensit adalah jarum sementit yang tersebar dalam matriks ferrit. Poligonal ferrit adalah ferrit yang berbentuk dengan banyak sudut. Struktur ini terbentuk akibat keluarnya karbon ke sekitar batas butir dengan cepat yang menyebabkan tepian batas butir memiliki banyak sudut. Fasa pada struktur ini adalah ferrit dikelilingi jaringan sementit yang tak beraturan. Menurut teori, fasa hasil perlakuan hardening adalah mastensit atau bainit. Martensit akan terbentuk pada baja dengan paduan karbon yang sukup tinggi dengan pendinginan yang sangat cepat, sedangkan fasa bainit terbentuk pada baja karbon rendah dengan pendinginan yang sedikit lebih lambat dari pendinginan martensit. Namun, jika dilihat pada diagram CCT HSLA fasa hasil perlakuan hardening pada penelitian ini terjadi pada rentang waktu yang tidak terlalu cepat, sehingga fasa yang terjadi adalah dominan bainit.

Proses hardening- tempering pada temperatur tempering $600^{\circ} \mathrm{C}$ dengan lama waktu tahan 2 jam menghasilkan struktur mikro upper bainit, asikular ferrit dan poligonal ferrit. Struktur poligonal ferrit yang terbentuk lebih banyak dan luas dibandingkan dari perlakuan hardening. Sedangkan upper bainit lebih sedikit. Pada proses hardening-tempering pada temperatur tempering $600^{\circ} \mathrm{C}$ dengan lama waktu tahan 3 jam menghasilkan struktur mikro asikular ferrit dan poligonal ferrit. Bainit tidak nampak pada struktur mikro ini, hal ini dikarenakan semakin lama waktu tahan tempering maka transformasi tidak akan menyentuh daerah upper bainit pada diagram CCT HSLA. Begitu pula dengan poligonal ferrit semakin lama waktu tahan maka ukuran poligonal ferrit semakin berkurang dan mengecil. Pada Pada proses hardening- tempering pada temperatur tempering $600^{\circ} \mathrm{C}$ dengan lama waktu tahan 4 jam struktur yang terbentuk adalah asikular ferrit dan poligonal ferrit. Pada perlakua ini daerah asikular ferrit semakin luas dan daerah poligonal ferrit semakin mengecil.

Perubahan struktur mikro dengan berbagai variasi perlakuan sesuai dengan diagram CCT HSLA, dimana semakin lama waktu tahan tempering pada temperatur $600^{\circ} \mathrm{C}$ maka struktur yang terbentuk cenderung semakin homogen.

\section{B. Uji Mekanik}

\section{B.1. Uji Tarik}

Gambar 2 menunjukkan sifat kekuatan luluh dan kekuatan tarik baja AAR M201 Grade E dengan variasi perlakuan panas.

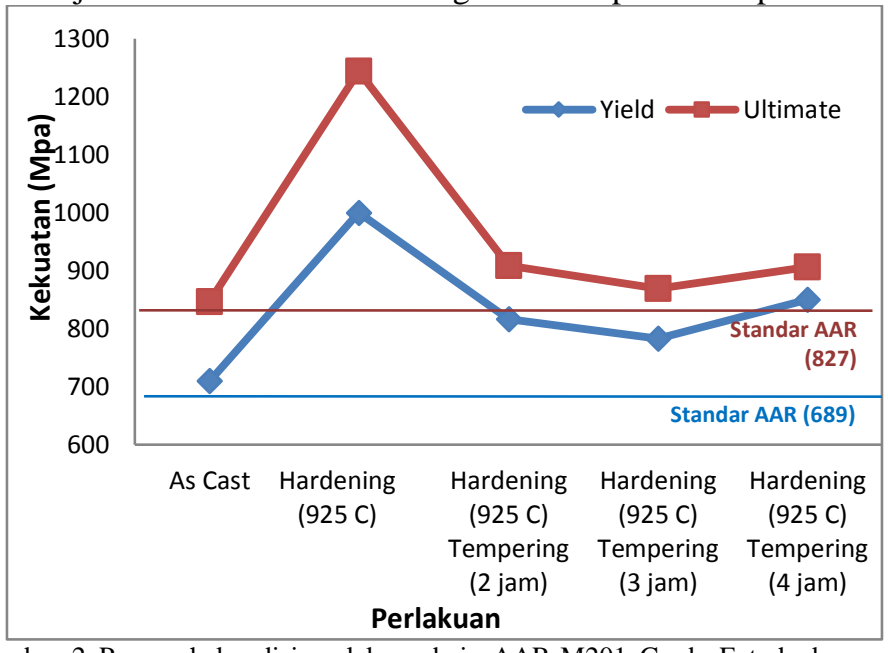

Gambar 2 Pengaruh kondisi perlakuan baja AAR-M201 Grade E terhadap kekuatan luluh dan kekuatan maksimum

Material as cast memiliki nilai kekuatan luluh sebesar 709 MPa. Kekuatan luluh meningkat setelah mengalami perlakuan hardening menjadi $1000 \mathrm{MPa}$. Pada material dengan perlakuan hardening-tempering dengan waktu tahan selama 2 jam, kekuatan luluh menurun menjadi $817 \mathrm{MPa}$. Pada hardeningtempering dengan waktu tahan selama 3 jam, kekuatan luluh menurun menjadi $782 \mathrm{MPa}$. Sedangkan pada hardeningtempering dengan waktu tahan selama 4 jam, kekuatan luluh naik menjadi $850 \mathrm{MPa}$.

Material as cast memiliki nilai uji tarik sebesar $847 \mathrm{MPa}$. Kekuatan tarik meningkat setelah mengalami perlakuan hardening, menjadi $1244 \mathrm{MPa}$. Pada material dengan perlakuan hardening-tempering dengan waktu tahan selama 2 jam, 
kekuatan tarik menurun menjadi $909 \mathrm{MPa}$. Pada hardeningtempering dengan waktu tahan selama 3 jam, kekuatan tarik menurun menjadi $870 \mathrm{MPa}$. Sedangkan pada hardeningtempering dengan waktu tahan selama 4 jam, kekuatan tarik naik menjadi $906 \mathrm{MPa}$.

Berdasarkan spesifikasi American Association of Railroads (AAR), spesifikasi kekuatan luluh dan kekuatan tarik minimal baja AAR-M201 Grade E adalah $827 \mathrm{MPa}$ dan $689 \mathrm{MPa}$. Kekuatan luluh dan kekuatan tarik akan meningkat akibat perlakuan hardening. Namun akan menurun akibat perlakuan tempering yang diberikan. Kekuatan luluh dan kekuatan tarik hasil penelitian memenuhi spesifikasi AAR.

Gambar 3, menunjukkan nilai keuletan AAR-M201 Grade E dengan variasi perlakuan panas.

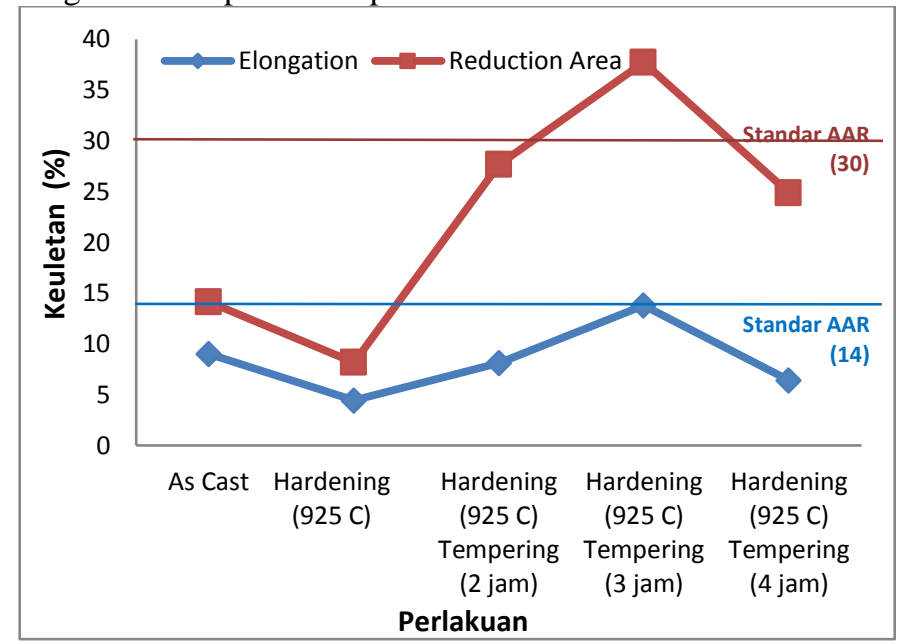

Gambar 3 Pengaruh kondisi perlakuan baja AAR-M201 Grade E terhadap persen elongasi dan reduksi area

Material as cast memiliki nilai elongasi sebesar 9\%. Elongasi menurun setelah mengalami perlakuan hardening menjadi $4 \%$. Pada material dengan perlakuan hardening-tempering dengan waktu tahan selama 2 jam, elongasi meningkat menjadi $8 \%$. Pada hardening-tempering dengan waktu tahan selama 3 jam, elongasi meningkat menjadi $14 \%$. Sedangkan pada hardeningtempering dengan waktu tahan selama 4 jam, elongasi turun kembali menjadi $6 \%$.

Material as cast memiliki nilai reduksi area sebesar $14 \%$. Reduksi area menurun setelah mengalami perlakuan hardening, menjadi 8\%. Pada material dengan perlakuan hardeningtempering dengan waktu tahan selama 2 jam, reduksi area meningkat menjadi 28\%. Pada hardening-tempering dengan waktu tahan selama 3 jam, reduksi area meningkat menjadi $38 \%$. Sedangkan pada hardening-tempering dengan waktu tahan selama 4 jam, reduksi area menurun kembali menjadi $25 \%$.

Berdasarkan spesifikasi American Association of Railroads (AAR), spesifikasi elongasi dan reduksi area minimal baja AAR-M201 Grade E adalah14\% dan 30\%. Elongasi dan reduksi area akan menurun akibat perlakuan hardening. Namun akan meningkat akibat perlakuan tempering yang diberikan. Elongasi dan resuksi area yang memenuhi spesifikasi AAR pada hardening-tempering dengan lama waktu tahan 3 jam.

\section{B.2. Uji Fatik}

Uji kelelahan dilakukan untuk untuk mengetahui masa kerja dari material setelah perlakuan panas. Pada baja AAR-M201
Grade E dengan kondisi perlakuan panas hardening $925^{\circ} \mathrm{C}$, kemudian di temper $600^{\circ} \mathrm{C}$ dengan lama waktu tahan 3 jam memiliki nilai fatigue live 5100 cycle. Nilai tersebut didapat dengan memberikan beban bending sebesar 0,9 nilai kekuatan luluh baja AAR-M201 grade Eyaitu 176 Psi.

\section{B.3. Uji Kekerasan}

Gambar 4 menunjukkan kekerasan baja AAR M201 Grade E dengan variasi perlakuan panas.

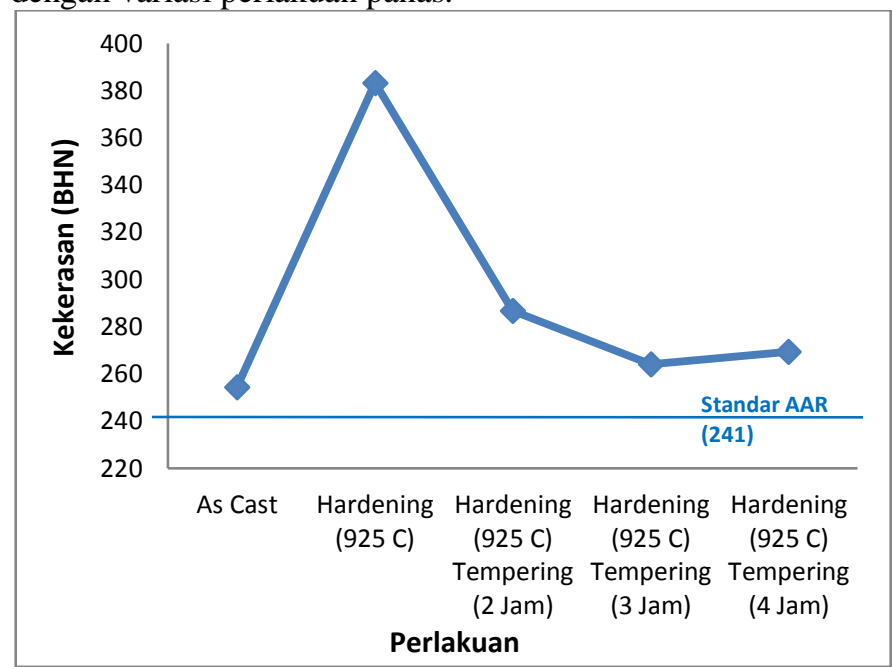

Gambar 4 Pengaruh kondisi perlakuan baja AAR-M201 Grade E terhadap kekerasan (BHN)

Material as cast memiliki nilai kekerasan sebesar 254 BHN. Nilai kekerasan meningkat setelah mengalami perlakuan hardening, menjadi 383 BHN. Pada material dengan perlakuan hardening-tempering dengan waktu tahan selama 2 jam, kekerasan menurun menjadi 287 BHN. Pada hardeningtempering dengan waktu tahan selama 3 jam, kekerasan menurun menjadi 264 BHN. Sedangkan pada hardeningtempering dengan waktu tahan selama 4 jam, kekerasan naik kembali menjadi 269 BHN.

Berdasarkan spesifikasi American Association of Railroads (AAR), spesifikasi kekerasan minimal baja AAR-M201 Grade E adalah 241 BHN. Kekerasan akan meningkat akibat perlakuan hardening. Namun akan menurun akibat perlakuan tempering yang diberikan. Nilai kekerasan yang memenuhi spesifikasi AAR adalah semua semua variasi perlakuan panas.

\section{B.4. Uji Impak}

Gambar 5 menunjukkan nilai impak baja AAR-M201 Grade E dengan varisasi waktu tahan tempering. Pengujian dilakukan pada temperatur $0,-40$, dan $-60^{\circ} \mathrm{C}$. 


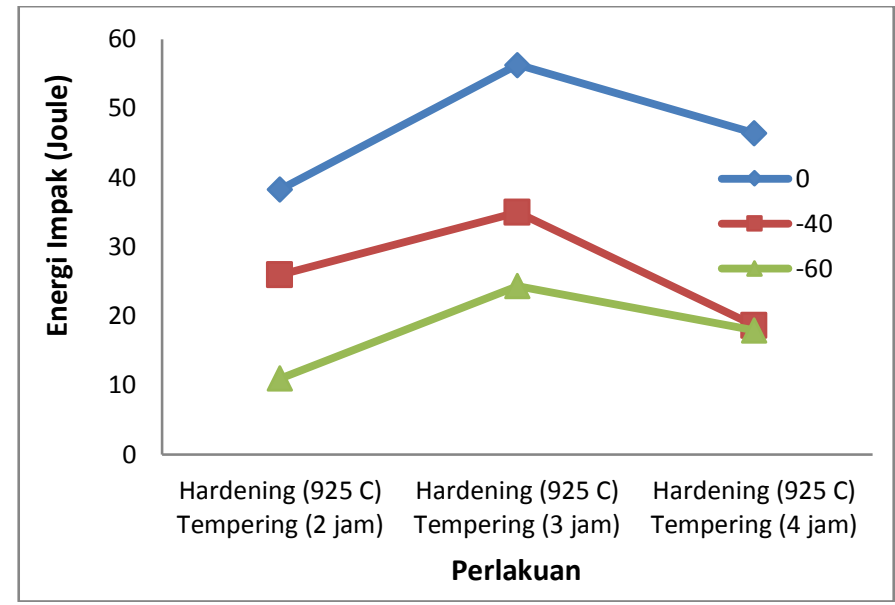

Gambar 4 Pengaruh kondisi perlakuan baja AAR-M201 Grade E terhadap kekuatan impak pada berbagai temperatur $\left(0,-40,-60^{\circ} \mathrm{C}\right)$

Pada temperatur $0^{\circ} \mathrm{C}$ material dengan perlakuan hardeningtempering dengan waktu tahan 2 jam memiliki energi impak sebesar 38 Joule. Energi impak naik pada perlakuan hardeningtempering dengan waktu tahan 3 jam menjadi 56 Joule dan turun kembali pada perlakuan hardening-tempering dengan waktu tahan 4 jam menjadi 47 Joule. Pada temperatur $-40^{\circ} \mathrm{C}$ material dengan perlakuan hardening-tempering dengan waktu tahan 2 jam memiliki energi impak sebesar 26 Joule. Energi impak naik pada perlakuan hardening-tempering dengan waktu tahan 3 jam menjadi 35 Joule dan turun kembali pada perlakuan hardening-tempering dengan waktu tahan 4 jam menjadi 19 Joule. Demkian pula pada temperatur $-60^{\circ} \mathrm{C}$ material dengan perlakuan hardening-tempering dengan waktu tahan 2 jam memiliki energi impak sebesar 11 Joule. Energi impak naik pada perlakuan hardening-tempering dengan waktu tahan 3 jam menjadi 24 Joule dan turun kembali pada perlakuan hardeningtempering dengan waktu tahan 4 jam menjadi 18 Joule.

Gambar 6 menunjukkan kekuatan impak dengan variasi perlakuan panas pada pengujian dengan temperatur $-40^{\circ} \mathrm{C}$.

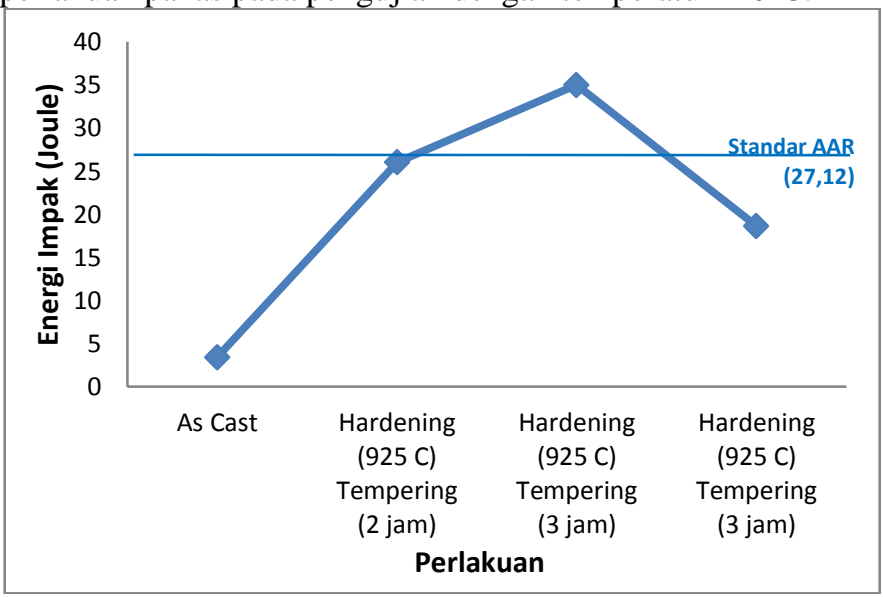

Gambar 5 Pengaruh kondisi perlakuan baja AAR-M201 Grade E terhadap kekuatan impak pada temperatur $-40^{\circ} \mathrm{C}$

Material as cast memiliki nilai energi impak sebesar 3 Joule. Berdasarkan spesifikasi Association of American Railroads (AAR), energi impak minimum yang harus dimiliki oleh baja AAR-M201 Grade E adalah sebesar 27 Joule pada temperatur $40^{\circ} \mathrm{C}$. Energi impak berbanding lurus dengan keuletan.
Spesimen yang memenuhi standar AAR adalah spesimen hardening-tempering pada waktu tahan 3 jam.

Kekuatan merupakan kemampuan benda kerja menerima beban. Struktur mikro benda kerja berpengaruh pada kekuatan dan kekerasan. Pada material as cast, struktur yang terbentuk adalah asikular ferrit dan grain boundary ferrite. Dimana kekuatan dan kekerasan cenderung rendah dibanding dengan hasil perlakuan hardening. Struktur mikro hasil hardening adalah upper bainit, poligonal ferrit dan martensit. Jumlah martensit pada perlakuan ini cenderung sedikit sehingga tidak menaikkan kekuatan dan kekerasan secara signifikan. Bainit memiliki karateristik seperti bilah, mirip deformasi twin dan plat martensit. Pembentukan bilah bainit diikuti oleh distorsi permukaan sehingga dapat disimpulkan terjadi pergeseran kisi. Peningkatan kekuatan dan kekerasan ini melalui mekanisme penguatan deformasi (Abbaschian, 2009). Proses tempering yang dilakukan menurunkan kekuatan dan kekerasan benda kerja. Kekuatan dan kekerasan pada setiap tahap tempering berhubungan dengan ruang antar partikel, ukuran butir, ukuran partikel dan distribusi, dan densitas dislokasi. Kekerasan dan kekuatan tarik akan berkurang selama tempering (Bhadeshia, 2009). Struktur mikro yang terbentuk pada perlakuan tersebut adalah upper bainit, poligonal ferrit dan asikular ferrit. Semakin lama waktu tahan tempering maka struktur mikro bainit semakin berkurang dan semakin di dominasi dengan asikular ferrit bila dilihat dari digram CCT HSLA. Selain struktur mikro bainit yang semakin berkurang seiring kenaikkan lama waktu tahan, poligonal ferrit berkurang dan semakin mengecil. Struktur mikro pada waktu tahan paling lama dominan asikular ferrit. Asikular ferrit memiliki proses pembentukan struktur yang hampir sama dengan bainit dan memiliki kekuatan dan kekerasan diantara ferrit dan bainit, selain untuk menaikkan kekuatan dan kekerasan, asikular ferrit dapat meningkatkan ketangguhan benda kerja. Tidak heran jika kekuatan dan kekerasan pada struktur mikro dominan asikular ferrit akan semakin meningkat. Selain kekuatan dan kekerasan, nilai ketahanan lelah benda kerja berbanding lurus dengan ketangguhan.

Keuletan material as cast cukup rendah. Ketika benda kerja menerima perlakuan hardening, dengan seiring meningkatnya kekuatan dan kekerasan maka keuletan semakin menurun. Pada perlakuan tempering, yang bertujuan mengurangi tengangan sisa pada benda kerja, mampu meningkatkan keuletan benda kerja. Semakin lama waktu tahan tempering maka keuletan semakin meningkat, hal ini berbanding terbalik dengan kekuatan dan kekerasan (Callister, 2009). Selain meningkatkan keuletan, energi impak pada temperatur tertentu bertambah besar apabila waktu tahan tempering bertambah (Dieter, 1990).

Hampir semua pengujian memiliki kecenderungan (trend) yang tidak sesuai dengan teori yang ada, seperti pada nilai kekuatan, keuletan, kekerasan dan kekuatan impak. Misal pada waktu tahan 3 jam dan 4 jam yang seharusnya memiliki nilai keuletan yang cenderung naik, namun pada variasi ini nilai keuletan menjadi turun, dan pada semua pengujian terjadi ketidak-sesuaian trend yang sama secara teoritis pada waktu tahan 4 jam. Hal ini disebabkan unsur paduan penstabil karbida Mn yang tinggi pada baja sehingga semakin lama waktu pemanasan (pada waktu tertentu) maka karbida akan semakin stabil. Selain Mn sebagai penstabil karbida ada pula unsur paduan $\mathrm{Cr}$ dan Mo sebagai pembentuk karbida yang kuat, dan 
$\mathrm{Cr}$, Mo, $\mathrm{Cu}$ dan Ni sebagai penstabil karbida. Maka ketika waktu tahan semakin tinggi (pada waktu tertentu) unsur-unsur penstabil dan pembentuk karbida tersebut mengakibatkan peningkatan kekuatan dan kekerasan baja (secondary hardness). Selain itu bila dilihat dari struktur mikro pada waktu tahan tempering selama 4 jam, struktur semakin homogen. Struktur yang homongen akan menghasilkan kekuatan dan kekerasan yang tinggi.

Hasil yang paling optimal didapat dari proses tempering dengan lama waktu tahan 3 jam, karena semua sifat mekanik memenuhi standar AAR. Sementara pada 2 variasi lama waktu tahan lainnya tidak memenuhi pada elongasi, reduksi area dan kekuatan impaknya. Nilai fatigue life pada lama waktu tahan tempering 3 jam sebesar 5100 cycle. Nilai fatigue life tersebut termasuk dalam high cycle finite life fatigue $\left(10^{3}-10^{6}\right.$ cycle $)$.

\section{KESIMPULAN/RINGKASAN}

Pada penelitian ini telah dilakukan mengenai analisa pengaruh lama waktu tahan tempering pada perlakuan panas terhadap perubahan struktur mikro dan sifat mekanik coupler baja AAR-M201 Grade E, maka diperoleh kesimpulan sebagai berikut,

1. Lama waktu tahan tempering mempengaruhi struktur mikro baja AAR-M201 Grade E. Tempering pada baja AAR-M201 Grade E menghasilkan struktur mikro asikular ferrit. Peningkatan temperatur tempering mengakibatkan struktur menjadi semakin halus (menyebar merata) antara ferrit dan karbida sementit $\left(\mathrm{Fe}_{3} \mathrm{C}\right)$, yang semula cenderung menyisakan poligonal ferrit menjadi cenderung terbentuk asikular ferrit.

2. Lama waktu tahan tempering mempengaruhi sifat mekanik baja AAR-201 Grade E. Semakin lama waktu tahan pada proses tempering menyebabkan kekuatan luluh, kekuatan maksimum, dan kekerasan menurun, serta keuletan dan energi impak meningkat. Hasil sifat mekanik yang sesuai adalah proses tempering pada lama waktu tahan 3 jam, menghasilkan nilai kekuatan tarik $870 \mathrm{MPa}$, kekuatan luluh $782 \mathrm{MPa}$, elongasi $14 \%$, reduksi area 38\%, kekerasan 264 BHN, kekuatan impak sebesar 35 Joule pada temperatur $40^{\circ} \mathrm{C}$ dan nilai fatigue life 5100 cycle. Nilai yang dihasilkan seluruhnya memenuhi standar AAR.

\section{DAFTAR PUSTAKA}

[1] 2007. Manual of Standards and Recommended Practices. Washington D.C.: The Association of American Railroads.

[2] 2001. Manual of Standards and Recommended Practices: $\overline{\text { Couples }}$ and Freight Car Draft Components. Washington D.C.: The Association of American Railroads.

[3] 2010. ASTM E10 : Standard Test Method for Brinell Hardness of Metallic Materials. ASTM International.

[4] 2002. ASTM E23 : Standard Test Methods for Notched Bar Impact Testing of Metallic Materials. ASTM International.

[5] 2007. ASTM E3 : Standard Guide for Preparation of Metallographic Specimens. ASTM International.

[6] 1998. ASTM E606 - 92 : Standard Practice Strain-Controlled Fatigue Testing. ASTM International.

[7] 2007. ASTM E8/E8M : Standard Test Methods for Tension Testing of Metallic Materials. ASTM International.

[8] 2008. ASTM A370 : StandardTest Methodes and Definition for Mechanical Testing of Steel Products. ASTM International.
[9] Abbaschian, Reza, Robert, E., Reed-Hill. 2009. Physical Metalurgy Principles. 4th edition. Boston: PWS Publishing Company.

[10] Avner, Sidney H. 1974. Introduction to Physical Metallurgy. New York: Mc.Graw Hill Publishing Co. Inc.

[11] Bhadhesia, H. K. D. H., dan R. W. K. Honeycombe. 2006. Steels: Microstructure and Properties. Oxford: Elsevier.

[12] Callister, William D. 2009. Materials Science and Engineering an Introduction. Vol. 7. New York: John Wiley \& Sons. Inc.

[13] Dieter, G.E. 1990. Mechanical Metallurgy.SI Metric Edition. Singapore: McGraw-Hill.

[14] Huang, Jin, Lu Xia, Youshou Zhang, dan Sinian Li. 2014. "Investigation on Brittle Fracture Mechanism of a Grade E Cast Steel Knuckle." Case Studies in Engineering Failure Analysis: 15-24. 